\title{
Ecologically realistic model of infection for exploring the host damage caused by Vibrio aestuarianus
}

\author{
Parizadeh Leila ${ }^{1}$, Tourbiez Delphine ${ }^{1}$, Garcia Céline ${ }^{1}$, Haffner Philippe ${ }^{1,2}$, Dégremont Lionel ${ }^{1}$, \\ Le Roux Frédérique ${ }^{3,{ }^{*}}$, Travers Marie-Agnès ${ }^{1}$
}

${ }^{1}$ Laboratoire de Génétique et Pathologie des Mollusques Marins, SG2M-LGPMM; Ifremer; Avenue de Mus de Loup 17390 La Tremblade France

2 IHPE UMR 5244, CNRS-Ifremer-UM-UPVD; Université de Montpellier; Place Eugène Bataillon - CC80 34095 Montpellier Cedex 05

${ }^{3}$ Ifremer, Unité Physiologie Fonctionnelle des Organismes Marins; ZI de la Pointe du Diable, CS 10070

F-29280 Plouzané France

* Corresponding author : Frédérique Le Roux, email address : fleroux@sb-roscoff.fr

\begin{abstract}
:
Although vibrios are frequently associated with marine organisms mortality outbreaks, knowledge on their ecology and pathogenicity is sparse, thus limiting disease management and prophylactic strategies. Here, we investigated $V$. aestuarianus infection onset and progression in the wild, taking advantage of a "claire" pond: a semi-closed system with limited seawater renewal, theoretically more adapted to disease transmission. We showed a positive association of the bacteria with oysters, which can constitute a reservoir for the bacteria in the winter. Moreover, passage through oysters was found to be necessary for experimental disease reproduction as vibrios shedding from diseased oysters has higher infectivity than from in vitro grown. We next developed an experimental "ecologically realistic" infection model in a mesocosm, allowing infection by natural route. By means of this non-invasive protocol, we analysed the pathogenesis of the bacteria and demonstrated the importance of haemolymph for initial colonisation and the septicaemic nature of this disease.
\end{abstract}


59 Owing to its potential for rapid growth and its remarkable tolerance to various environmental

60 conditions, the oyster Crassostrea gigas has become one of the most important aquaculture

61 animals and is established in many regions of the world (Chaney and Gracey, 2011)

62 representing an important socioeconomic and cultural activity in coastal areas. Nonetheless,

63 the intensification of $C$. gigas farming has coincided with mass mortality events threatening

64 the sustainability of this industry. In France, since 2008, mortality outbreaks of juvenile

65 oysters have considerably increased in frequency and intensity, with mortality levels currently

66 ranging between $60 \%$ and $90 \%$ (Barbosa Solomieu et al., 2015). Various research efforts have

67 mainly focused on the hypothesis that these events result from the emergence of a new

68 genotype of the herpes virus, OsHV-1 $\mu$ var (Segarra et al., 2010; Martenot et al., 2011;

69 Schikorski et al., 2011a; Schikorski et al., 2011b; Martenot et al., 2013; Barbosa Solomieu et

70 al., 2015). On the other hand, it has been observed that rapid colonisation by diverse vibrios

71 precedes replication of OsHV-1 when oysters are incubated in the field during a mortality

72 outbreak (Petton et al., 2015). In the absence of bacteria, a high load of the herpes virus is not

73 sufficient to induce the full manifestation of the disease (Petton et al., 2015), while antibiotic

74 treatment has strongly reduced oyster mortality rates, revealing a role of bacteria in the

75 disease transmission and development (Lemire et al., 2014; Petton et al., 2015; Bruto et al.,

76 2017). Thus, a consensus tends to define oyster juvenile syndrome as a polymicrobial disease

77 involving OsHV-1 $\mu$ var and diverse populations of Vibrio although the role of each

78 pathogenic agent remains to be determined.

79 Even more worrying is the increase in frequency of oyster mortality outbreaks associated with

80 the presence of $V$. aestuarianus since 2012 because this vibriosis affects the adult stage of the

81 animal and causes ineluctable losses for the farmers (Travers et al., 2015). Genotyping

82 analyses showed that $V$. aestuarianus strains isolated from diseased oysters cluster into two 
nearly identical clonal lineages (A and B), whereas isolates sampled from healthy oysters,

84 cockles, or zooplankton were found to be more diverse (Goudenege et al., 2015). Within each

85 of the two lineages A and B, a majority of strains are virulent, suggesting that a few strains

86 have recently lost their pathogenicity. In line with this hypothesis, a single-nucleotide

87 deletion, inducing a frame shift in the varS gene that codes for the transduction histidine-

88 protein kinase of sensory system VarS/VarA (Lenz et al., 2005), was linked to a loss of

89 virulence in one strain. The varS gene is intact in all the virulent strains, and genetic analyses

90 confirmed its role in the infection of oysters and in expression of a secreted metalloprotease

91 (Goudenege et al., 2015).

92 To date, knowledge about the pathogenesis of $V$. aestuarianus infection and especially the

93 route of infection remains scarce (Vezzulli et al., 2015; Le Roux et al., 2016) and has been

94 mainly based on experimental injection involving a single cultivated strain (Labreuche et al.,

95 2006b; Garnier et al., 2007; Labreuche et al., 2010). A gene encoding a metalloprotease (vam)

96 has been previously implicated in $V$. aestuarianus virulence as an effector. When expressed

97 from a plasmid by a non-pathogenic Vibrio strain (Labreuche et al., 2010), this gene induces

98 the same immunosuppressive effects on haemocytes as those observed for $V$. aestuarianus

99 extracellular products, i.e. inhibits their phagocytic abilities and adhesion capacity (Labreuche

100 et al., 2006a).

101 However, major questions regarding the ecology and biology of $V$. aestuarianus must be

102 addressed prior to diagnose, predict or eventually prevent oyster disease outbreaks. First, what 103 are the persistence and dynamics of $V$. aestuarianus in the environment? Previous $V$. 104 aestuarianus samplings has been biased toward moribund animals, i.e. without taking into 105 consideration the microbial community in the water column to which oysters are connected.

106 Vibrio are ubiquitous in marine ecosystems and can adopt different lifestyles from free living 107 to particle-attached or animal-associated (Hunt et al., 2008). A previous study has proposed 
108 that during the cold seasons, $V$. aestuarianus may subsist on the sediment, from which it can

109 emerge in the warmest months (Azandegbe et al., 2010). Second, what is the infection route

110 of $V$. aestuarianus? Intramuscular injection of bacterial suspensions or putative exotoxins into

111 the animal adductor muscle has been widely used in oysters as an experimental infection

112 model, allowing for high-throughput screening of bacterial isolates with good reproducibility.

113 Nevertheless, this technique does not reflect the natural route of infection, thus precluding 114 other factors that may influence the onset and pathology of disease (e.g. chemotaxis, 115 colonisation), and the method of infection by immersion frequently does not result in any 116 mortality at all (Le Roux et al., 2016).

117 Here, we investigated the disease ecology of $V$. aestuarianus. Oysters were deployed in a 118 pond, a semi-closed system with limited seawater renewal, to characterise the spatiotemporal 119 dynamics of oyster infection by $V$. aestuarianus at fine scale. At different time points, $V$. 120 aestuarianus was detected in distinct habitats (seawater fractions, sediment, and oysters) that 121 are connected by dispersal. Our analysis revealed that $V$. aestuarianus is preferentially 122 associated with oysters, and its presence in healthy oysters can be revealed in cold months by 123 thermal stress. All isolated strains belong to lineage A and are virulent. We next developed an 124 experimental infection system in a mesocosm that enables oyster infection via a natural route, 125 and we described the histopathological damage associated with $V$. aestuarianus.

127 RESULTS AND DISCUSSION

\section{Natural infection by $\boldsymbol{V}$. aestuarianus: an experimental design}

130 To investigate the dynamics of oyster infection in the field, we used specific pathogen free 131 (SPF) oysters that are descendants of a pool of genitors that are produced in hatcheries under 
132 highly controlled conditions (Lemire et al., 2014; Petton et al., 2015; Le Roux et al., 2016).

133 These animals are not axenic, as is the case with gnotobiotic animals (Marques et al., 2006);

134 however, OsHV-1 and $V$. aestuarianus DNAs were not detected, and the load of total vibrios

135 remained low for the SPF oysters analysed before the experiments $(<1$ colony-forming units

136 [cfu] per milligram of tissue). In October 2014, batches of SPF oysters (herein termed

137 recipients, $\mathrm{n}=1500$ ) were placed in two distinct ponds, with the first pond (designated as 138 pond A) containing $V$. aestuarianus-infected oysters (donors, $\mathrm{n}=2000$ ), and with the second

139 pond (designated as pond B) containing only SPF oysters (recipients, $\mathrm{n}=1500$ ). For 15

140 weeks, mortality rates were recorded weekly and were observed only in the first pond (donors

141 and recipients). On five dates (weeks $0,3,6,9,15), 50$ living recipients were sampled. Thirty

142 of these animals were used to collect haemolymph, detect the presence of $V$. aestuarianus or

143 OsHV-1 by quantitative PCR (qPCR), and to isolate the bacteria; meanwhile, the 20

144 remaining oysters were used to allow development of the disease in tanks at $25^{\circ} \mathrm{C}$. On five

145 dates, seawater was sampled, and particles were fractionated by size to collect zooplankton

146 (60 $\mu \mathrm{m}$ plankton net), large phytoplankton, and organic particles, smaller organic particles and

147 free-living bacterial cells $(5,1$, and $0.22 \mu \mathrm{m}$ pore size filters, respectively). Sediment and

148 interstitial seawater were also sampled. It should be noticed that $V$. aestuarianus cannot be

149 isolated on Vibrio-selective media such as TCBS (Azandegbe et al., 2010). Hence, half of all

150 samples and filters served for DNA extraction and $V$. aestuarianus detection by qPCR and half

151 for bacterial isolation on Zobell agar plates and for subsequent screening of $V$. aestuarianus

152 isolates (see the Materials and Methods section for details).

154 Spatiotemporal dynamics of oyster infection by $\boldsymbol{V}$. aestuarianus

155 In pond A, mortality was lower than $10 \%$ during the first 3 weeks (Figure 1) and dramatically 156 increased between weeks 3 and 8 thus reaching $42 \%$. Subsequently, mortality slightly 
157 increased during the 8 next weeks, reaching $49 \%$ at the end of the experiment. The peak of 158 mortality coincided with a temperature ranging from $15^{\circ} \mathrm{C}$ to $20^{\circ} \mathrm{C}$ and salinity $\sim 32 \mathrm{~g} / \mathrm{L}$, 159 although correlation between daily mortalities and temperature was weak $\left(\mathrm{R}^{2}=0.49\right)$ (Figure

160 1). In the laboratory, animals collected after staying for 3, 6, 9, and 15 weeks in pond $A$, 161 experienced cumulative mortality of $60 \%, 60 \%, 50 \%$, and $20 \%$, respectively, within the 162 following 7 days in the laboratory (Figure 1, red bar). OsHV-1 DNA was never detected in 163 these animals (data not shown). No mortality was observed among unexposed animals 164 maintained at $25^{\circ} \mathrm{C}$ in the laboratory.

166 Total-vibrio and $V$. aestuarianus DNAs were detected in seawater fractions, sediment, and 167 living oyster haemolymph at different time points, i.e. 0, 3, 6, 9, and 15 weeks (Figures 2 and $168 \mathrm{~S} 1)$. $V$. aestuarianus was never detected in zooplankton. On day 0, V. aestuarianus was 169 detected only as free living $\left(10^{3}\right.$ bacteria per litre). After 3,6 , and 9 weeks, the total vibrio 170 load was estimated to be $10^{1}, 10^{2}$, and $10^{3}$ bacterial cells per litre, respectively, for large 171 phytoplankton and organic particles, smaller organic particles, and free-living bacterial cells. $172 V$. aestuarianus accounted for up to $1 \%$ of all the vibrio cells (i.e. genome copies) in some 173 fractions and on some dates of sampling, i.e. free living at weeks 0, 3, 6 and 9, smaller 174 organic particles at week 3,6 and 9, and large phytoplankton and organic particles at week 9 175 (Table S1). Considering the overall results in seawater, $V$. aestuarianus was found to be 176 differentially distributed in different fractions ( $p$ value $=3.22 \mathrm{e}-05$, Kruskal-Wallis test), with 177 preferential association with the planktonic fraction ( $p$ values $<0.05$, pairwise comparisons, 178 Wilcoxon test). This finding suggests that $V$. aestuarianus does not have to be attached to 179 particles or integrated into marine aggregates to infect oysters, as previously demonstrated for 180 V. vulnificus (Froelich et al., 2013). In the sediment, V. aestuarianus DNA accounted for up to $18118 \%$ of vibrio cells ( 5 bacterial cells $/ \mathrm{mg}$ ) but was detected only after 9 weeks (Table S1), 
suggesting that the persistence of $V$. aestuarianus in the sediment during the cold season as

183 proposed by Azandegbe et al. (2010) is unlikely.

$185 V$. aestuarianus was found to be abundant in oyster haemolymph of living oysters $\left(10^{5}\right.$

186 bacteria per millilitre of haemolymph) at week 3, 6, and 9, when $V$. aestuarianus was

187 estimated to represent 25 to $30 \%$ of all vibrio cells. Fisher's exact test and odds ratio analysis

188 revealed a significant positive correlation between oysters and $V$. aestuarianus $\left(p=6.10^{-12}\right.$,

189 odds ratio $95 \%$ confidence interval $[12.4554 ; \infty])$ suggesting that $V$. aestuarianus is

190 preferentially associated with oyster haemolymph. During the epidemic phase (week 3, 6 and

$1919), V$. aestuarianus abundance reached 2.5 to $5.6 \times 10^{5}$ bacteria/ $\mathrm{ml}$ in live oysters and its

192 prevalence was estimated around 50 to $60 \%$ (Figures 1 and S1). Of note, at week 15, it was

193 not possible to detect $V$. aestuarianus in oysters sampled in the pond, although $20 \%$ of the

194 animals experienced further mortality when maintained in tanks at $25^{\circ} \mathrm{C}$ (Figures 1 and S1).

195 As $V$. aestuarianus strains were isolated from moribund animals collected in tanks (see

196 below), it appeared that at a low temperature $\left(\sim 5^{\circ} \mathrm{C}\right.$, see Figure 1) oysters were infected by $V$.

197 aestuarianus at a load that is undetectable by our diagnostic method (threshold of $<10^{2}$

198 bacteria per millilitre) but can be revealed in the laboratory by a thermal stress assay. Such

199 persistence of vibrio at a low concentration in the host has been previously described for the

200 human pathogen $V$. parahaemolyticus (Olafsen et al., 1993; DePaola et al., 2003) and may

201 constitute a risk factor for disease spread when oysters are moved between production areas

202 for farming purposes. Our results are in agreement with other data (Petton et al., 2015),

203 showing that oysters can asymptomatically carry putative pathogens, thus raising concerns

204 about the role of oysters as pathogen reservoirs. We can speculate here that thermal stress in

205 the laboratory can be applied to diagnose asymptomatic carriage of a pathogen (Petton et al., 206 2015). 
208 We next attempted to isolate $V$. aestuarianus strains from DNA-positive samples. Among 592

209 colonies isolated from seawater and sediment fractions, only one strain, originating from a

210 free-living fraction and sampled at week 0, was identified as $V$. aestuarianus (Table S2). A

211 total of 212 out of 734 bacteria isolated from oysters collected at weeks 3, 6, and 9 were

212 identified as $V$. aestuarianus, confirming the findings about the abundance and prevalence of

213 this species in the haemolymph of diseased animals. In addition, we were able to isolate $48 \mathrm{~V}$.

214 aestuarianus strains from moribund animals sampled in the tank after the development of the

215 disease by thermal stress. All the 261 isolated $V$. aestuarianus strains belong to clade A

216 (Goudenege et al., 2015) with 100\% identity within the partial sequences of $l d h$ previously

217 used to differentiate the two virulent lineages within the species. A total of 227 strains

218 (including the strain isolated in seawater) were tested for virulence by injection of $10^{2}$ bacteria

219 into oysters, and all of them induced high mortality, i.e. > 70\% (data not shown). Genotyping

220 and virulence assays did not reveal a diversity of the strains infecting oysters and may suggest

221 a clonal expansion of infected animal by virulent genotype(s)

\section{Infection by $\boldsymbol{V}$. aestuarianus in a mesocosm}

224 We previously observed that $V$. aestuarianus is transmitted from donor to recipient oysters mainly as a free-living bacterium. We next determined whether an oyster transiently

226 immersed into bacteria-contaminated water would contract the disease. When a virulent $V$.

227 aestuarianus strain (12_016a) cultivated in a rich medium was employed for infection via

228 bath $\left(5 \times 10^{8} \mathrm{cfu} / \mathrm{L}\right)$ the obtained results lacked reproducibility, i.e. mortality was observed in

229 six out of 14 distinct experiments (Figure S2). We then hypothesised that virulence of $V$.

230 aestuarianus (and consequently reproducibility of the immersion model of infection) may be

231 improved when bacteria are shed from infected oysters. Oysters were injected with the 
232 12_016a strain $\left(10^{7} \mathrm{cfu} /\right.$ animal $)$ and maintained for $48 \mathrm{~h}$ under static conditions. $V$. 233 aestuarianus load in contaminated seawater (CSW) was estimated by qPCR and adjusted to 5

$234 \times 10^{8} \mathrm{cfu} / \mathrm{L}$ (for details see Materials and Methods). SPF oysters were then exposed to CSW 235 for $24 \mathrm{~h}$, washed, and transferred to a new tank containing UV-treated water. After this 236 procedure, deaths were observed in 16 out of 17 distinct experiments (Figure S2), suggesting 237 that the virulence of $V$. aestuarianus strengthens in vivo. This result has been previously 238 demonstrated on $V$. cholerae in which specific genes are induced in vivo and favour further 239 infection by increasing persistence in the stool and/or aquatic environments (Schild et al., 240 2007). Indeed, the transcriptome of human-shed vibrios differs substantially from that of in 241 vitro-grown $V$. cholerae, resulting in a hyper-infectious state (Merrell et al., 2002; Alam et al., 242 2005; Butler et al., 2006).

$244 V$. aestuarianus strain 12_016a and its $\Delta$ varS derivative (hereafter abbreviated as WT and $245 \Delta v a r S$, respectively, for simplicity) have been previously shown to induce similar mortality $246(80-100 \%)$ when injected into oysters at a high dose $\left(10^{7} \mathrm{cfu} / \mathrm{animal}\right)$, whereas only the wild247 type strain induces significant mortality when injected at a low dose $\left(10^{2} \mathrm{cfu} / \mathrm{animal}\right)$ 248 (Goudenege et al., 2015). When injected at a high dose, shedding of $1 \times 10^{8}$ to $2 \times 10^{8}$ 249 bacterial cells/animal was noticed for both strains, resulting in a similar load of WT and $250 \Delta$ varS in $\mathrm{CSW}$ (thereafter termed $\mathrm{CSW}_{\mathrm{wt}}$ or $\mathrm{CSW}_{\Delta}$ ) and can thus be used for experimental 251 infection by immersion (Figure 3). By this procedure, when oysters were immersed in $\mathrm{CSW}_{\mathrm{wt}}$, 252 mortality was observed after an initial latent phase of 3 days (phase 1), reached $30 \%$ on day 6 253 (phase 2), stabilised for 4 days (phase 3), increased to $40 \%$ on day 14 (phase 4), and then 254 ceased. These dynamics suggest that 3-4 days are necessary for freshly shed bacteria to kill an 255 oyster. Immersion in $\mathrm{CSW}_{\Delta}$ induced maximal mortality of $7 \%$ after 7 days, while no deaths 256 occurred when oysters were immersed in UV-treated seawater as a control (Figure 3). 
257 Altogether these results suggest that deletion of the gene encoding regulator VarS affects the 258 ability of $V$. aestuarianus to colonise oysters. In the future, transcriptomic analyses should 259 allow to decipher which genes and biological processes are controlled by VarS and involved 260 in oyster infection.

\section{Dynamics of $V$. aestuarianus infection in the host}

263 Our experimental infection system in a mesocosm enables oyster infection via a non-invasive 264 approach and hence should be of prime interest for identification of the natural route of 265 infection with $V$. aestuarianus.

266 The kinetics of infection of each strain (WT and $\Delta v a r S$ ) were first explored by qPCR analysis 267 using DNA extracted from living and moribund animals' tissues and haemolymph (up to 15 268 animals/strain per sampling point; Figure 4). V. aestuarianus was never detected in animals 269 incubated in UV-treated seawater. On day 1, V. aestuarianus was detected exclusively in the 270 haemolymph of $73 \%$ and $23 \%$ of living animals of strains WT and $\Delta v a r S$, respectively. On 271 day 4, V. aestuarianus was detected only in the tissues (haemolymph, gills, digestive gland, 272 mantle, muscle, and palps) of living animals infected by the WT strain, whereas this bacterial 273 species could not be detected in the tissues of oysters infected with the $\Delta v a r S$ mutant. Here we 274 observed that a $\Delta v a r S$ mutant is unable to persist in the hemolymph. In moribund animals 275 infected with WT, we observed an increase of bacterial load by four orders of magnitude in 276 the haemolymph, by comparison with living animals $\left(3 \times 10^{4}\right.$ bacterial cells/haemocyte in 277 moribund oysters vs $10^{1}$ bacterial cells/haemocyte on day 1 ). In the other tissues, the loads 278 were found to be similar (mean of $5 \times 10^{2}$ bacterial cells in moribund oysters, standard error 279 (SE): $1 \times 10^{2}$ ). Our results revealed early colonisation of haemolymph by $V$. aestuarianus and 280 its capacity for proliferation in this fluid, thereby causing bacterial spread inside the animals. 281 As previously shown for $V$. crassostreae (Bruto et al., 2017), V. aestuarianus is abundant in 
282 haemolymph, considered the most hostile environment in the animals, i.e. containing the 283 immunocompetent cells and various immune effectors and soluble factors produced by the 284 haemocytes to protect the oyster from infections (Schmitt et al., 2010). This situation raises 285 the question of haemolymph colonisation as a common trait of oyster pathogens, although the 286 mechanisms of interaction with haemocytes may be different. For instance, $V$. tasmaniensis 287 strain LGP32 has evolved the ability to survive in haemocytes (Duperthuy et al., 2011) and 288 induces cytolysis by expressing antioxidant and copper resistance mechanisms (Vanhove et 289 al., 2016). V. aestuarianus, by contrast, induces haemocyte impairments probably through an 290 oxidative disequilibrium. Moreover, it can adhere to haemocytes (Pezzati et al., 2015), and

291 inhibits cell adhesion and phagocytosis through its extracellular products (Labreuche et al., 292 2006a), in particular, metalloprotease Vam (Labreuche et al., 2010), thus indicating a strategy 293 of extracellular multiplication (Labreuche et al., 2006b).

\section{V. aestuarianus-associated damage}

296 Histopathological damage and localisation of $V$. aestuarianus in diverse tissues were next

297 confirmed on sacrificed animals, by histology and immunohistochemistry with a polyclonal 298 antibody. Here again, V. aestuarianus was never detected in control animals (Figure 5A) 299 presenting normal tissue structures (Figure 6A, C, E).

300 It is important to note that except in advanced cases of haemocyte infiltration, blood spaces 301 generally appeared empty (Martoja and Martoja, 1967), limiting our interpretation of 302 circulating bacteria at the initial stages of the disease, because of such histological methods.

303 On day 1, the WT (Figure 5B and Table S3) and $\Delta$ varS (Table S3) strains were detected as few 304 foci in the gills of 5 out of 14 and 6 out of 10 animals, respectively. Nevertheless, as early as 305 this first day after bacterial contact, first signs of histological damage were observed (Figure 306 6, Table S4). These lesions could be classified into three classes: (type 1) lysis of the sub- 
307 epithelial connective tissue in the mantle (Figure 6B), (type 2) epithelial atrophy of digestive 308 diverticula (DD) with dilation of the diverticulum lumen (Figure 6D), and (type 3) haemocyte 309 lysis and/or infiltration by haemocytes and/or haemocyte agglutination in haemolymph 310 vessels (Figure 6F-H). Even though each of these lesions cannot be defined as specific to this 311 disease (Couch, 1984; Knowles et al., 2014; Martenot et al., 2016), the presence of all of them

312 in field oysters is generally noticed in $V$. aestuarianus-infected animals sampled during 313 surveillance programs (REPAMO Network, Céline Garcia, personal communication) and 314 should constitute a part of a diagnostic method.

316 On day 4, $\Delta v a r S$ was detected in gills (3 of 10 animals) and rarely in the digestive gland (1 of

31710 animals), whereas the bacteria were not detected in the other seven animals, thereby 318 indicating bacterial clearance and/or the absence of initial infection (Table S3). Even though 319 few lesions were detected on day 1 in the animals immersed in the $\operatorname{CSW}_{\Delta v a r S}$, we did not 320 notice any progression of the damage on day 4 either in the percentage of affected animals or 321 in lesion intensity (Table S4). Taken together, these results revealed the absence of 322 progression of the disease in the $\Delta v a r S$-infected animals.

324 By contrast, in oysters immersed in $\mathrm{CSW}_{\mathrm{wt}}$ and sampled on day 4 , bacteria were detected in 325 most of the individuals (13 of 15). In those samples, two bacterial distribution patterns 326 corresponding to two different disease stages were observed. We thus defined two groups. For 3276 of 8 animals (termed Group a, Figure 5C), V. aestuarianus was localised to only one tissue: 328 the gills. In contrast, for 7 out of 7 animals (termed Group b, Figure 5D), intense colonisation 329 of all oyster tissues was observed. To be precise, stained bacteria-like cells were detected i) in 330 gills, as attached to epithelial cells or as isolated cells, ii) around the digestive gland in 331 connective tissues as well as attached or inside epithelial cells of the digestive tissue, iii) in 
332 the mantle, in clusters in connective tissues, iv) in between muscular fibres of the adductor 333 muscle, and v) in the periphery of the sinus, vein, or artery of different tissues. The disease 334 progression on day 4 was associated with an increase of affected animals for the 3 types of 335 lesions (Table S4), as well as an increase in lesion intensity (an increase in the number of 336 affected areas and significant atrophy of the DD epithelium as compared to the control). 337 Finally, damage intensity increased reaching a maximum in moribund animals, in which $V$. 338 aestuarianus was detected in every tissue of all the tested animals (Figure 5E). These results 339 confirmed the septicaemic characteristics of $V$. aestuarianus infection.

340 Finally, the $V$. aestuarianus route of infection can be summarised by 5 steps: (1) early 341 colonisation of haemolymph by a virulent strain, (2) bacterial multiplication in this fluid (3) 342 accompanied by haemocyte recruitment and lysis, and finally (4) invasion of other connective 343 tissues (5) in which damage was noticed. Considering the limited ability of non-virulent strain $344 \Delta$ varS to colonise the haemolymphatic system and to invade other tissues, our results point 345 again to the role of haemolymph in pathogen selection. This fluid has, thus, to be considered 346 with interest for future studies dealing with early diagnosis and prophylactic strategies. 
354 Animals

355 SPF juveniles were generated as previously described (Petton et al., 2015). A batch of SPF 356 oysters (intended for a field survey) was produced in January and April 2014 (Ifremer 357 Argenton, Brittany, France) and transferred to Ifremer La Tremblade (Charente Maritime, 358 France) in May 2014. At the time of their transfer into ponds (see below) their mean total 359 weight was $19.6 \pm 3.8 \mathrm{~g}$ (mean \pm SD) and their mean size $56.1 \pm 4.3 \mathrm{~mm}$. Biparental families 360 of SPF oysters were also produced in January 2015 (Ifremer La Tremblade) for experimental 361 pathological analysis. At the start of the experiment, oysters were 18 months old, weighed

$36224.2 \pm 5.7 \mathrm{~g}$ and had a size of $61.2 \pm 8.1 \mathrm{~mm}($ mean $\pm \mathrm{SD})$. Oysters were maintained in $240 \mathrm{~L}$ 363 raceways with a continuous UV-treated seawater flow and an ad libitum phytoplankton diet 364 (Isochrysis galbana, Tetraselmis suecica, and Skeletonema costatum).

365 Twelve oysters were screened before experiments for the eventual presence of $V$. aestuarianus 366 and OsHV-1 herpes virus by standard protocols (Pepin et al., 2008; Saulnier et al., 2009).

\section{Bacteria}

369 Bacteria: strains, growth conditions, and suspensions

370 V. aestuarianus strain 12/016 (a highly pathogenic strain isolated during an oyster mortality 371 episode) and its mutant variant 12/016 $\Delta \operatorname{var} S$ (a mutation in the varS gene) (Goudenege et al., 372 2015) were used for bacterial challenges in this study. $V$. aestuarianus strains were grown in 373 Zobell agar (peptone $4 \mathrm{~g} / \mathrm{L}$, yeast extract $1 \mathrm{~g} / \mathrm{L}$, Tris- $\mathrm{HCl}$ buffer $0.5 \mathrm{~g} / \mathrm{L}$, ferric citrate $0.1 \mathrm{~g} / \mathrm{L}$, 
374 agar $15 \mathrm{~g} / \mathrm{L}$ in $1 \times$ artificial seawater, $\mathrm{pH} 7.4$ ) at $22^{\circ} \mathrm{C}$. The Vibrio suspension was obtained 375 from an isolate stored at $-80^{\circ} \mathrm{C}$ in the Zobell medium containing $15 \%$ glycerol (v/v). The 376 bacterial strain was placed in the liquid Zobell medium and incubated for $24 \mathrm{~h}$ at $22^{\circ} \mathrm{C}$ with 377 constant shaking at $20 \mathrm{rpm}$. The resulting suspension was centrifuged at $3000 \mathrm{rpm}$ for $10 \mathrm{~min}$

378 at room temperature. The supernatant was discarded, and the pellet was resuspended in sterile 379 artificial sea water (SASW). The bacterial concentration was evaluated 380 spectrophotometrically at $600 \mathrm{~nm}$ and adjusted to optical density (OD) of $1.0\left(5.10^{8}\right.$ bacterial 381 cells $/ \mathrm{mL}$ ). Purity and concentration of the bacteria were checked by plating on Zobell agar.

\section{Field survey}

\section{Natural infection by $\boldsymbol{V}$. aestuarianus in a pond}

385 Next, 1500 SPF juveniles (mean total weight $19.6 \pm 3.8 \mathrm{~g}[$ mean $\pm \mathrm{SD}$ ]; size $56.1 \pm 4.3 \mathrm{~mm}$ )

386 were transferred into two non-submersible individual ponds commonly called "claires" in 387 France (La Tremblade, Charente Maritime, France) from October $7^{\text {th }}, 2014$, to February $1^{\text {st }}$, 388 2015. Ponds had an average depth of approximately $70 \mathrm{~cm}$ for a volume of $250 \mathrm{~m} 3$. The two 389 ponds were $5 \mathrm{~km}$ away and were naturally supplemented with seawater during the spring 390 tides, when the tidal coefficient exceeds 85 . One of these ponds initially contained 2000 391 animals supposed to be partially infected with $V$. aestuarianus. Subsequent analyses of those 392 animals confirmed that they were carriers of the bacteria (Lionel Degrémont, personal 393 communication). Mortality and environmental parameters (temperature and salinity) were 394 recorded each week (340i, WTW). At five sampling points (see below), 30 live oysters were 395 collected, and haemolymph was withdrawn for bacterial culture and DNA extraction (see 396 above). Additionally, each week, 20 oysters were sampled and then transferred to the 397 laboratory located $200 \mathrm{~m}$ away from the pond. The oysters were placed in one tank filled with 
398 UV-treated seawater, which was aerated and maintained at $25^{\circ} \mathrm{C}$. Mortality was recorded daily

399 for 7 days, and moribund animals were removed and analysed by detection and quantification

400 of $V$. aestuarianus and herpes virus OsHV-1. In the second pond, one sampling was performed

401 at week 0 . Additionally, animals were submitted to thermal choc on weeks 0,3 and 6 . In

402 absence of $\mathrm{V}$. aestuarianus detection and of any noticeable mortality (in the pond B during the

40315 weeks of survey and in lab), additional samplings were not performed.

\section{Seawater and sediment sampling in the pond}

406 Seawater and sediment from the pond were sampled on September $29^{\text {th }}$, October $27^{\text {th }}$, 407 November $17^{\text {th }}$, and December $8^{\text {th }}, 2014$, as well as on February $1^{\text {st }}, 2015$. Two litres of 408 seawater was successively filtered at $60,5,1$, and $0.22 \mu \mathrm{m}$ pore size through polycarbonate 409 (PC) filters. Half of the filters were subjected to DNA-based quantification of $V$. aestuarianus 410 (see below), and the other half of the filters were directly plated on the Zobell medium at $41122^{\circ} \mathrm{C}$ for bacterial isolation (see below). Twenty millilitres of sediment and interstitial 412 seawater was sampled into syringes, plated after agitation (10 $\mathrm{min})$ and serial dilution up to $41310^{-3}$ on the Zobell medium, and stored at $-20^{\circ} \mathrm{C}$ for DNA extraction.

\section{Quantification of $\boldsymbol{V}$. aestuarianus DNA in oysters, seawater, and sediment: a pond survey}

416 Total DNA was extracted from the haemolymph of live oysters, and filters were used to detect $417 V$. aestuarianus in seawater by means of the QIAamp Tissue Mini Kit (Qiagen) or 418 NucleoSpin ${ }^{\circledR}$ Genomic DNA from Tissue Kit (Macherey-Nagel). Total DNA was extracted 419 from sediment with the PowerSoil DNA Isolation Kit (MoBio). DNA concentrations were 420 measured using a spectrophotometer (Nanodrop, Thermo Fischer) before storage at $-20^{\circ} \mathrm{C} . V$. 
421 aestuarianus DNA quantification was carried out via a qPCR protocol (Saulnier et al., 2009)

422 on Mx3000 and Mx3005 Thermocyclers (Agilent). Amplification reactions were carried out

423 in duplicate, in a total volume of $20 \mu \mathrm{L}$. Each well contained $5 \mu \mathrm{L}$ of genomic DNA (5

$424 \mathrm{ng} / \mu \mathrm{L}$ ), $10 \mu \mathrm{L}$ of the Brillant III Ultra-Fast Master Mix (Agilent), $0.060 \mu \mathrm{L}$ of each primer at

$425100 \quad \mu \mathrm{M} \quad$ (DNAj-F $\quad$ 5'-GTATGAAATTTTAACTGACCCACAA, DNAj-R 5'-

426 CAATTTCTTTCGAACAACCAC), $\quad 0.040 \mu \mathrm{L}$ of DNAj probe $100 \mu \mathrm{M} \quad\left(5^{\prime}-\right.$

427 TGGTAGCGCAGACTTCGGCGAC), and $4.84 \mu \mathrm{L}$ of distilled water. qPCR cycling 428 conditions were as follows: $3 \mathrm{~min}$ at $95^{\circ} \mathrm{C}$, followed by 40 cycles of amplification at $95^{\circ} \mathrm{C}$ for $42910 \mathrm{~s}$ and $60^{\circ} \mathrm{C}$ for $20 \mathrm{~s}$. By a similar protocol, total Vibrio DNA was estimated with 567F430 680R primers (Thompson et al., 2004).

432 For experimental colonisation analyses, bacterial DNA concentrations were normalised in 433 each sample to an oyster gene (elongation factor gene $=\mathrm{Cg}$-EF, 5'434 AGTCACCAAGGCTGCACAGAAAG-3'; 5'-TCCGACGTATTTCTTTGCGATGT-3').

435 Firstly, the copy numbers of genes, dnaJ and $C g-E F$, were estimated by means of genomic 436 DNA of $V$. aestuarianus and a plasmid containing the $C$. gigas EF gene, respectively (Segarra 437 et al., 2014) as standards. Briefly, standards were prepared using the relation between the 438 concentration of DNA and the theoretical copy number of a genome or plasmid, calculated on 439 the basis of the DNA mass divided by molecular weight of the genome or of the plasmid. 440 They were also validated by the limit dilution method, assuming that the dilution at which 1 441 replicate in 10 was positive corresponds to 1 copy. The absence of amplification (no $\mathrm{Ct}$ ), or 442 unquantifiable values (outside the standard range) were labelled as 1 copy and 10 copies 443 respectively. Finally, the ratio $\log 10$ (absolute quantification of $V$. aestuarianus dnaJ) $\div$ $444 \log 10$ (absolute quantification of $C$. gigas EF) was calculated. The relative stability of our 
445 reference gene between individuals $(\mathrm{Ct})$ was checked to ensure consistency of our normalised

446 results (bacterial cells/haemocytes $v s$ bacterial cells/ml of haemolymph).

448 Bacterial isolation, identification, and typing: a pond survey

449 Serially diluted samples (two sediment samples, 30 oyster haemolymph samples) and 5, 1, 450 and $0.22 \mu \mathrm{m}$ PC filters were plated on Zobell medium at $22^{\circ} \mathrm{C}$ with incubation for $48 \mathrm{~h}$. From 451135 to 460 colonies were boiled in distilled water and tested by qPCR as described above at 452 each sampling time point to isolate as many $V$. aestuarianus clones as possible. All colonies 453 positive for dnaJ amplification were re-streaked twice and stored at $-80^{\circ} \mathrm{C}$. For DNA 454 sequencing, $5 \mu \mathrm{L}$ of boiled DNA extract $\left(10 \mathrm{~min}\right.$ at $\left.95^{\circ} \mathrm{C}\right)$ was added to a PCR mix (GoTaq 455 G2, Promega) for lactate dehydrogenase (ldh) amplification (Goudenege et al., 2015). The 456 PCR conditions were as follows: $5 \mathrm{~min}$ at $95^{\circ} \mathrm{C}$, followed by 30 cycles of $30 \mathrm{~s}$ each of $95^{\circ} \mathrm{C}$ 457 and $58^{\circ} \mathrm{C}$ and $1 \mathrm{~min}$ at $72^{\circ} \mathrm{C}$, with a final step of $7 \mathrm{~min}$ at $72^{\circ} \mathrm{C}$. Universal PCR analysis 458 targeting the 16S rRNA gene (universal primers SAdir S17rev) was performed on negative 459 results to confirm the absence of inhibitors in DNA extracts.

460 The partial $l d h$ sequences were aligned with Muscle and phylogenetic trees were built in 461 MEGA 6 (http://www.megasoftware.net/) by the maximum likelihood algorithm, with the 462 GTR model, and reliability was assessed by the bootstrap method with 1000 replicates.

464 Experimental infection

465 Bacterial virulence estimation by injection

466 Bacteria were grown with constant agitation at $22^{\circ} \mathrm{C}$ for $24 \mathrm{~h}$ in the Zobell medium. One

467 hundred microliters of diluted culture $\left(10^{2} \mathrm{cfu}\right.$, estimated as $\mathrm{OD}_{600}$ of 0.002 and checked by 
468 plating on Zobell agar) was injected intramuscularly into anesthetised SPF oysters. After 469 injection, the oysters were transferred to aquaria (10 oysters per aquarium of $2.5 \mathrm{~L}$, triplicate 470 aquaria per bacterial strain) containing $1 \mathrm{~L}$ of aerated UV-treated seawater at $22^{\circ} \mathrm{C}$, kept under

471 static conditions for 5 days.

473 Experimental immersion infection: immersion into seawater containing cultured 474 bacteria

475 Seawater containing cultured bacteria was produced from a diluted concentrated bacterial

476 suspension prepared as described above to reach a final concentration of $\sim 5 \times 10^{8}$ bacterial 477 cells/L. Sentinel oysters were immersed for $24 \mathrm{~h}$ in this water before 2-week following in 478 fresh UV-treated seawater. This experiment was reproduced over time (14 times).

480 Experimental immersion infection: immersion into seawater containing freshly shed 481 bacteria

482 The first step of this protocol corresponds to production of CSW, i.e. containing freshly shed 483 bacteria. Source oysters (biparental families) were anaesthetised for $4 \mathrm{~h}$ at $22^{\circ} \mathrm{C}$ in a solution 484 of magnesium chloride (50 g/L of freshwater) with aeration. The oysters were subsequently 485 injected with $50 \mu \mathrm{L}$ of one of the different bacterial suspensions into the adductor muscle. 486 Afterwards, the animals (30 to 50 oysters for each condition) were placed into a tank 487 containing $12 \mathrm{~L}$ of UV-treated seawater maintained under static conditions (one tank per 488 strain). A control has been realised in the same condition by injection of SASW. After $48 \mathrm{~h}, V$. 489 aestuarianus concentration in CSW was estimated by qPCR and was adjusted to $5 \times 10^{8}$ to 1 $490 \times 10^{9}$ bacterial cells/L. 
491 Sentinel animals (biparental families) were then exposed to this CSW or to seawater as 492 control for $24 \mathrm{~h}$ under static and aerated conditions. Finally, after these $24 \mathrm{~h}$ of contamination,

493 infected and control oysters were transferred into new tanks containing UV-treated seawater.

494 This experiment was reproduced over time (17 times).

496 Sampling and mortality monitoring for histopathological analysis

497 During one experiment on freshly shed bacteria, eight tanks were designated for sampling (15 498 animals/tank, 4 tanks per condition, 3 conditions: oysters exposed to virulent 12/016 strain, 499 oysters exposed to non-virulent 12/016 mutant and oysters not exposed to the bacteria). At 500 different time points after infection (day 1 and day 4), haemolymph was sampled from the 501 posterior adductor muscle sinus, by gentle aspiration with a $1 \mathrm{~mL}$ syringe equipped with a 22502 G needle. Quality of samples was systematically checked by microscopic examination before 503 use. Pieces of gills, of the mantle, adductor muscle, digestive gland, and labial palps were 504 dissected and stored at $-20^{\circ} \mathrm{C}$. Finally, a half of the animal was fixed for histological analysis 505 as described below.

506 The four other tanks were designated for mortality estimation. Examination of mortality was 507 performed daily for 14 days. A dead oyster was defined as a moribund animal that was unable 508 to close its valve after $5 \mathrm{~min}$ out of water. To confirm that the mortality is due to $V$. 509 aestuarianus, haemolymph was sampled in moribund animals. From $100 \mu \mathrm{L}$, DNA was 510 extracted, and $V$. aestuarianus DNA was quantified by dnaJ qPCR as described above. In 511 parallel, haemolymph samples were spread on the Zobell agar medium, and predominant 512 bacteria were subjected to $d n a J$ qPCR to identify $V$. aestuarianus clones.

515 Oyster fixation and labelling for histopathological analysis: 


\section{Fixation}

517 Oyster samples were preserved in Davidson's fixative (22\% formaldehyde, $33 \%$ ethanol $95^{\circ}$ 518 proof, $12 \%$ glycerol, $33 \%$ of $0.22 \mu \mathrm{m}$-filtered seawater, and $10 \%$ acetic acid) for $48 \mathrm{~h}$ and

519 then stored in ethanol before embedding in paraffin wax blocks. From each block of paraffin, 520 consecutive 3- to 5 - $\mu$ m-thick sections were cut off and adhered to Superfrost (H\&E) or 521 Superfrost Plus (IHC) microscope slides.

\section{Haematoxylin and eosin (H\&E) staining}

524 The $C$. gigas tissue slices were deparaffinised and stained with Histalim (Montpellier), by 525 means of standard Harris' H\&E stain according to ref. (Hayat, 1993), and mounted with the 526 Eukitt Mounting Medium (O. Kindler $\mathrm{GmbH}$ ). The slices were viewed under a microscope 527 (Olympus BX50) coupled to a camera (Leïca DMC 2900). The slides were digitised by a 528 Nanozoomer scanner (Hamamatsu) with a light background, via a $20 \times$ objective, without a Z 529 stack. For lesions, beyond any abnormal characteristics, we mostly noticed the presence of 530 necrosis, atrophy, and haemocyte infiltration into different tissues: gills, gonads, digestive 531 glands, the mantle, muscle, kidney, and digestive tube. The lesions intensity in each organ was 532 coded as follows: 0 (absence of a lesion); 1 (low), 2 (medium), and 3 (high). Moreover, for 533 DD, lumen area of $30 \mathrm{DD} /$ slide was measured in 14 oysters infected with WT, 12 oysters 534 infected with the $\Delta$ varS strain, and in four non-infected oysters (NDP.view2, 535 Hamamatsu.com).

\section{Immunohistochemical analysis (IHC)}

538 Immunostaining with Histalim (Montpellier) was performed on a Benchmark automate 539 (Ventana-Roche). Briefly, oyster tissue slices were prepared and deparaffinised as described 540 above, and next pre-hybridised in immunohistochemistry buffer (Tris/EDTA pH 8.9). The pre- 
541 hybridisation solution was replaced with fresh immunohistochemistry buffer containing a

542 rabbit polyclonal anti-[Va] primary antibody (gift from JL Nicolas, LPI Ifremer Plouzané) for

$5431 \mathrm{~h}$ at a 1:20 000 dilution. The specificity of this antibody was firstly tested by western

544 blotting and dot blotting, and the conditions were optimised. After washing and incubation

545 with a secondary antibody, analysis with the Ultraview Red AP Kit (Roche Diagnostics) was

546 performed. The slices were viewed under a microscope (Olympus BX50) coupled to a camera

547 (Leïca DMC 2900). The slides were digitised by the Nanozoomer scanner (Hamamatsu)

548 against a light background, via a $20 \times$ objective, without a $\mathrm{Z}$ stack. A negative control was set

549 up by omission of the primary antibody.

551 Statistical analyses

552 These analyses were performed in the XLSTAT software (Version 2011.4.02). To validate the 553 ecological preferences of $V$. aestuarianus and to study the distribution in oyster haemolymph 554 and seawater, the Kruskal-Wallis and Fisher's exact tests and odds ratio analysis were 555 performed. To compare the DD lumen between the control and infected animals sampled at 556 different time points, lumen perimeters were compared by the Mann-Whitney test. 
561 Figure 1 : Oyster disease dynamic on field. The $7^{\text {th }}$ October 2014 (week $0, x$ axis) SPF oysters (recipient, $\mathrm{n}=1500$ ) were exposed to natural seawater in a pond containing $V$. aestuarianus-infected oysters (donor, $\mathrm{n}=2000$ ). During 15 weeks (x axis) mortality rates of the

564 recipients were recorded weekly (red line, \%, y axis). At each time point, temperature (blue 565 dotted line, ${ }^{\circ} \mathrm{C}$, y axis) and salinity (green dotted line, g/L, y axis) were measured.

566 At five dates (weeks $0,3,6,9,15)$, living animals $(n=20)$ were returned to the laboratory to 567 allow development of the disease in tanks at $25^{\circ} \mathrm{C}$ and their cumulative mortalities after 7 568 days are indicated by read bars (\%, y axis).

570 Figure 2: Quantification of $\boldsymbol{V}$. aestuarianus and total Vibrio DNA by qPCR (y axis) in 571 sediment (grey), seawater fractions (red, zooplankton; yellow, large phytoplankton and 572 organic particles; green, smaller organic particles; blue, free-living bacterial cells) and oyster 573 hemolymph (purple, average on 30 individuals) sampled at the indicated week (x axis) during 574 the field's survey (Figure 1). Quantifications are expressed as genome units per g in sediment, 575 per $\mathrm{L}$ in seawater and per $\mathrm{mL}$ in oyster hemolymph,

577 Figure 3: Oyster disease dynamic in mesocosm. Oysters $(n=30)$ were transiently immersed 578 (for $24 \mathrm{~h}$ ) in contaminated seawater containing $5.10^{8} \mathrm{cfu} / \mathrm{L}$ of $\mathrm{V}$. aestuarianus WT strain (red 579 line), and its $\Delta v a r S$ derivative (green line) or UV treated seawater (blue line), washed and 580 transferred to new tank containing UV treated water. Mortalities were recorded daily for 14 581 days ( $\mathrm{x}$ axis) and cumulative mortality rates are indicated in \% (y axis). The four different 582 infection phases are also indicated. 
583 Figure 4: Infection dynamics of $\boldsymbol{V}$. aestuarianus in animals infected with a highly 584 pathogenic strain (WT) and with a non-pathogenic strain ( $\Delta$ varS). V. aestuarianus DNA 585 amounts were quantified by qPCR in hemolymph (A), mantle (B), gills (C), muscle (D), 586 digestive gland (E) and palps (F). Scattergrams show the bacterial DNA copy number/cell. 587 The change in bacterial DNA concentration for each sample is depicted on the y axis as a data 588 point with the Log 10 DnaJ ( $V$. aestuarianus gene) normalized by Log10 Cg-EF (oyster 589 elongation factor $\mathrm{Cg}-\mathrm{EF}$ ). $\mathrm{X}$ axis represents the post infection sampling (d1: day1 post 590 infection; d4: day4 post infection and mo.: moribund animals). Red line corresponds to the 591 median. 15 animals were analyzed per time and per condition, except for controls for which 5 592 animals were sampled.

594 Figure 5: Bacterial colonization observed in individuals infected with virulent $V$. aestuarianus strain. Immunohistochemistry allowed us to identify 3 steps of infection: early

596 (B, day 1, 14 animals), intermediate (C-D, day 4, 15 animals) and moribund state (E, 4 597 animals). Two groups of distribution were noticed on day 4 and defined as intermediate group 598 a (C, 8 animals, labelling in gills only), and intermediate group b (D, 7 animals, labelling in 599 all tissues). Different tissues were studied: gills (G), digestive gland (DG), muscle (Mu), 600 mantle (Mtl) and labial palps (Plp) for controls and infected animals. With ultra view red kit, a $601 \mathrm{pink} /$ violet labeling of bacterial-like cells was observed in different tissues. All scale bars $=$ $602100 \mu \mathrm{m}$.

604 Figure 6: Histological sections from adult oysters stained by hematoxylin-eosin showing 6053 types of tissue lesions indicated by arrows. Upper sections (A-B) correspond to mantle, 606 middle sections (C-D) to digestive diverticula, and lower sections (E-H) to connective tissues 
607 and vessels with hemocytes. Sections A, C and E correspond to controls (8 animals studied) 608 and sections B, D, F-H to highly infected animals (4 animals studied). The different lesions 609 noticed are: (1) lysis of the subepithelial connective tissue in mantle (section B), (2) atrophy 610 of digestive diverticula with an increase in diverticulum lumen (section D), and (3) hemocyte 611 infiltrations (section F), lysis and agglutination (section $\mathrm{G}$ in sinus and section $\mathrm{H}$ in artera). *: 612 significant increase in lumen area. Scale bar $=100 \mu \mathrm{m}(\mathrm{A}-\mathrm{F})$ or $50 \mu \mathrm{m}(\mathrm{G}-\mathrm{H})$. 
616 Supplementary Figure 1: Quantification of $\boldsymbol{V}$. aestuarianus in oyster hemolymph

617 individuals by qPCR (genome units per $\mathrm{mL}, 30$ live animals, y axis) sampled at the indicated 618 week (x axis) during the field's survey (Figure 1). Means are represented by red crosses and 619 median by red lines.

621 Supplementary Figure 2: Oyster experimental infection by immersion into $V$. 622 aestuarianus contaminated waters. Oysters $(\mathrm{n}=30)$ were transiently immersed into waters 623 containing $5.10^{8} \mathrm{cfu} / \mathrm{L}$ of $V$. aestuarianus cultured overnight in a rich media, Zobell (14 624 distinct experiments, grey bars, $\mathrm{x}$ axis) or freshly shed from injected oysters (17 distinct 625 experiments, black bars, $\mathrm{x}$ axis). Cumulative mortalities rate obtained after 14 days are given 626 (y axis).

628 Supplementary Table1: Quantification of total vibrios (Tot) and $V$. aestuarianus ( $V$. $a$ ) 629 genome copy number in seawater fractions $(\mathrm{B} / \mathrm{L})$, in sediment $(\mathrm{B} / \mathrm{mg})$ and oyster hemolymph $630(\mathrm{~B} / \mathrm{ml})$ sampled at week 0, 3, 6, 9 and 15 during the field's survey (Figure 1). Percentage of $V$. aestuarianus out of total vibrios (ratio) is also indicated. nd: not determined, neg: no detection

633 Supplementary Table 2: Number of bacteria isolated at week 0, 3, 6, 9 and 15 in seawater

634 fractions and sediment, or oyster hemolymph during the field's survey (Figure 1) and 635 screened to identify $V$. aestuarianus strains. 
637 Supplementary Table 3: Number of individuals for which bacterial labeling was observed in 638 gills, digestive gland, mantle, labial palps or muscle. Control oysters (8 individuals) and 639 oysters infected with $V$. aestuarianus WT strain (33 individuals) or $\Delta v a r S$ derivative (20

640 individuals) were analyzed. Immunohistochemistry was performed using anti-aestu polyclonal 641 antibody and ultra view red kit. For individuals infected with WT and sampled on day 4, two 642 groups of individuals were defined based on the intensity and the repartition of the labeling 643 (Group a and b)

645 Supplementary Table 4: Number of individuals for which tissue lesions were observed in 646 mantle, digestive diverticula or hemolymphatic compartment. Oysters infected with $V$. 647 aestuarianus WT strain (33 individuals) or $\Delta v a r S$ derivative (20 individuals) were analyzed.

648 Intensity of lesions was coded, considering the frequency of observations on 5 random fields 649 of view for each tissue: low $=$ up to 5 observations, medium $=$ between 5 to 15 observations, 650 high $=$ more than 15 observations. For digestive diverticula atrophy, lumen areas were 651 measured (on 30 diverticula, on 3 random fields) with NDP.view2 and compared by t-test. 652 Observations were realized on hematoxylin eosin stained sections. For individuals infected 653 with WT and sampled on day 4, two groups of individuals were defined based on the labelling 654 observed by immunohistochemistry (table 4, Group a and b). 


\section{Acknowledgments}

658

659 This study was supported by a PhD grant from the IFREMER and Poitou-Charente Region for

660 L. Parizadeh (2014-2018).This study received financial support from the ANR (OPOPOP 661 project, 13-ADAP-0007-01) and the European commission (Vivaldi project, H2020 $\left.662 \mathrm{n}^{\circ} 678589\right)$

663 Special thanks go to Bruno Chollet, for technical assistance during microscopic analyses. We 664 also thank Mathilde Bazet, Mélodie Chapat and Niels Rapinel for their technical support for 665 pond survey and qPCR analyses. Acknowledgements finally go to Isabelle Arzul for her 666 precious advices on experimental design and to Maxime Bruto and Yannick Labreuche for 667 their comments and suggestions on the manuscript.

668 The authors declare that they have no conflict of interest.

669

670

671

672 
674 Alam, A., Larocque, R.C., Harris, J.B., Vanderspurt, C., Ryan, E.T., Qadri, F., and Calderwood, S.B. 675 (2005) Hyperinfectivity of human-passaged Vibrio cholerae can be modeled by growth in the infant 676 mouse. Infect Immun 73: 6674-6679.

677 Azandegbe, A., Garnier, M., Andrieux-Loyer, F., Kerouel, R., Philippon, X., and Nicolas, J.L. (2010) 678 Occurrence and seasonality of Vibrio aestuarianus in sediment and Crassostrea gigas haemolymph at 679 two oyster farms in France. Diseases of Aquatic Organisms 91: 213-221.

680 Barbosa Solomieu, V., Renault, T., and Travers, M.A. (2015) Mass mortality in bivalves and the 681 intricate case of the Pacific oyster, Crassostrea gigas. J Invertebr Pathol 131: 2-10.

682 Bruto, M., James, A., Petton, B., Labreuche, Y., Chenivesse, S., Alunno-Bruscia, M. et al. (2017) 683 Vibrio crassostreae, a benign oyster colonizer turned into a pathogen after plasmid acquisition. ISME $684 J$ 11: 1043-1052.

685 Butler, S.M., Nelson, E.J., Chowdhury, N., Faruque, S.M., Calderwood, S.B., and Camilli, A. (2006) 686 Cholera stool bacteria repress chemotaxis to increase infectivity. Mol Microbiol 60: 417-426.

687 Chaney, M.L., and Gracey, A.Y. (2011) Mass mortality in Pacific oysters is associated with a specific 688 gene expression signature. Mol Ecol 20: 2942-2954.

689 Couch, J. (1984) Atrophy of diverticular epithelium as an indicator of environmental irritants in the 690 oyster Crassostrea virginica. Mar Environ Res 14: 525-526.

691 DePaola, A., Nordstrom, J.L., Bowers, J.C., Wells, J.G., and Cook, D.W. (2003) Seasonal abundance 692 of total and pathogenic Vibrio parahaemolyticus in Alabama oysters. Appl Environ Microbiol 69: 693 1521-1526.

694 Duperthuy, M., Schmitt, P., Garzon, E., Caro, A., Rosa, R.D., Le Roux, F. et al. (2011) Use of OmpU 695 porins for attachment and invasion of Crassostrea gigas immune cells by the oyster pathogen Vibrio 696 splendidus. Proceedings of the National Academy of Sciences of the United States of America 108: 697 2993-2998.

698 Froelich, B., Ayrapetyan, M., and Oliver, J.D. (2013) Integration of Vibrio vulnificus into Marine 699 Aggregates and Its Subsequent Uptake by Crassostrea virginica Oysters. Applied and environmental 700 microbiology 79: 1454-1458.

701 Garnier, M., Labreuche, Y., Garcia, C., Robert, M., and Nicolas, J.L. (2007) Evidence for the 702 involvement of pathogenic bacteria in summer mortalities of the Pacific oyster Crassostrea gigas. 703 Microb Ecol 53: 187-196.

704 Goudenege, D., Travers, M.A., Lemire, A., Petton, B., Haffner, P., Labreuche, Y. et al. (2015) A single 705 regulatory gene is sufficient to alter Vibrio aestuarianus pathogenicity in oysters. Environ Microbiol 706 17: 4189-4199.

707 Hayat, M.A. (1993) Stains and cytochemical methods. In: Plenum Press, New York, pp. 63-64.

708 Hunt, D.E., David, L.A., Gevers, D., Preheim, S.P., Alm, E.J., and Polz, M.F. (2008) Resource 709 partitioning and sympatric differentiation among closely related bacterioplankton. Science 320: 10817101085.

711 Knowles, G., Handlinger, J., Jones, B., and Moltschaniwskyj, N. (2014) Hemolymph chemistry and 712 histopathological changes in Pacific oysters (Crassostrea gigas) in response to low salinity stress. $J$ 713 Invertebr Pathol 121: 78-84.

714 Labreuche, Y., Soudant, P., Goncalves, M., Lambert, C., and Nicolas, J.L. (2006a) Effects of 715 extracellular products from the pathogenic Vibrio aestuarianus strain 01/32 on lethality and cellular 716 immune responses of the oyster Crassostrea gigas. Dev Comp Immunol 30: 367-379. 
Labreuche, Y., Lambert, C., Soudant, P., Boulo, V., Huvet, A., and Nicolas, J.-L. (2006b) Cellular and molecular hemocyte responses of the Pacific oyster, Crassostrea gigas, following bacterial infection with Vibrio aestuarianus strain 01/32. Microbes and Infection 8: 2715-2724.

Labreuche, Y., Le Roux, F., Henry, J., Zatylny, C., Huvet, A., Lambert, C. et al. (2010) Vibrio aestuarianus zinc metalloprotease causes lethality in the Pacific oyster Crassostrea gigas and impairs the host cellular immune defenses. Fish \& shellfish immunology 29: 753-758.

723 Le Roux, F., Wegner, K.M., and Polz, M.F. (2016) Oysters and Vibrios as a Model for Disease

724 Dynamics in Wild Animals. Trends Microbiol 24: 568-580.

725 Lemire, A., Goudenege, D., Versigny, T., Petton, B., Calteau, A., Labreuche, Y., and Le Roux, F.

726 (2014) Populations, not clones, are the unit of vibrio pathogenesis in naturally infected oysters. ISME

$727 \mathrm{~J}$.

728 Lenz, D.H., Miller, M.B., Zhu, J., Kulkarni, R.V., and Bassler, B.L. (2005) CsrA and three redundant 729 small RNAs regulate quorum sensing in Vibrio cholerae. Mol Microbiol 58: 1186-1202.

730 Marques, A., Ollevier, F., Verstraete, W., Sorgeloos, P., and Bossier, P. (2006) Gnotobiotically grown

731 aquatic animals: opportunities to investigate host-microbe interactions. J Appl Microbiol 100: 903-

732918.

733 Martenot, C., Oden, E., Travaille, E., Malas, J.P., and Houssin, M. (2011) Detection of different 734 variants of Ostreid Herpesvirus 1 in the Pacific oyster, Crassostrea gigas between 2008 and 2010.

735 Virus Res 160: 25-31.

736 Martenot, C., Travaille, E., Lethuillier, O., Lelong, C., and Houssin, M. (2013) Genome exploration of 737 six variants of the Ostreid Herpesvirus 1 and characterization of large deletion in OsHV-1 muVar 738 specimens. Virus Res 178: 462-470.

739 Martenot, C., Segarra, A., Baillon, L., Faury, N., Houssin, M., and Renault, T. (2016) In situ

740 localization and tissue distribution of ostreid herpesvirus 1 proteins in infected Pacific oyster,

741 Crassostrea gigas. J Invertebr Pathol 136: 124-135.

742 Martoja, R., and Martoja, M. (1967) Initiation aux techniques de l'histologie animale. Masson et Cie, 743 Editeurs, 120 , bd St-Germain, Paris-VI.

744 Merrell, D.S., Hava, D.L., and Camilli, A. (2002) Identification of novel factors involved in 745 colonization and acid tolerance of Vibrio cholerae. Mol Microbiol 43: 1471-1491.

746 Olafsen, J.A., Mikkelsen, H.V., Giaever, H.M., and Hovik Hansen, G. (1993) Indigenous bacteria in

749 Pepin, J.F., Riou, A., and Renault, T. (2008) Rapid and sensitive detection of ostreid herpesvirus 1 in 750 oyster samples by real-time PCR. Journal of Virological Methods 149: 269-276.

751 Petton, B., Bruto, M., James, A., Labreuche, Y., Alunno-Bruscia, M., and Le Roux, F. (2015)

752 Crassostrea gigas mortality in France: the usual suspect, a herpes virus, may not be the killer in this

753 polymicrobial opportunistic disease. Frontiers in Microbiology 6: 686.

754 Pezzati, E., Canesi, L., Damonte, G., Salis, A., Marsano, F., Grande, C. et al. (2015) Susceptibility of 755 Vibrio aestuarianus 01/032 to the antibacterial activity of Mytilus haemolymph: identification of a 756 serum opsonin involved in mannose-sensitive interactions. Environmental Microbiology 17: 42717574279.

758 Saulnier, D., De Decker, S., and Haffner, P. (2009) Real-time PCR assay for rapid detection and 759 quantification of Vibrio aestuarianus in oyster and seawater: A useful tool for epidemiologic studies.

760 Journal of Microbiological Methods 77: 191-197.

761 Schikorski, D., Faury, N., Pepin, J.F., Saulnier, D., Tourbiez, D., and Renault, T. (2011a) Experimental 762 ostreid herpesvirus 1 infection of the Pacific oyster Crassostrea gigas: kinetics of virus DNA detection 763 by q-PCR in seawater and in oyster samples. Virus research 155: 28-34. 
764 Schikorski, D., Renault, T., Saulnier, D., Faury, N., Moreau, P., and Pepin, J.F. (2011b) Experimental 765 infection of Pacific oyster Crassostrea gigas spat by ostreid herpesvirus 1: demonstration of oyster 766 spat susceptibility. Veterinary research 42: 27.

767 Schild, S., Tamayo, R., Nelson, E.J., Qadri, F., Calderwood, S.B., and Camilli, A. (2007) Genes

768 induced late in infection increase fitness of Vibrio cholerae after release into the environment. Cell

769 Host Microbe 2: 264-277.

770 Schmitt, P., Gueguen, Y., Desmarais, E., Bachere, E., and de Lorgeril, J. (2010) Molecular diversity of 771 antimicrobial effectors in the oyster Crassostrea gigas. Bmc Evolutionary Biology 10.

772 Segarra, A., Pepin, J.F., Arzul, I., Morga, B., Faury, N., and Renault, T. (2010) Detection and 773 description of a particular Ostreid herpesvirus 1 genotype associated with massive mortality outbreaks 774 of Pacific oysters, Crassostrea gigas, in France in 2008. Virus Research 153: 92-99.

775 Segarra, A., Mauduit, F., Faury, N., Trancart, S., Degremont, L., Tourbiez, D. et al. (2014) Dual 776 transcriptomics of virus-host interactions: comparing two Pacific oyster families presenting contrasted 777 susceptibility to ostreid herpesvirus 1. BMC Genomics 15: 580.

778 Thompson, J.R., Randa, M.A., Marcelino, L.A., Tomita-Mitchell, A., Lim, E., and Polz, M.F. (2004) 779 Diversity and Dynamics of a North Atlantic Coastal Vibrio Community. Applied and Environmental 780 Microbiology 70: 4103-4110.

781 Travers, M.A., Boettcher Miller, K., Roque, A., and Friedman, C.S. (2015) Bacterial diseases in 782 marine bivalves. J Invertebr Pathol 131: 11-31.

783 Vanhove, A.S., Rubio, T.P., Nguyen, A.N., Lemire, A., Roche, D., Nicod, J. et al. (2016) Copper 784 homeostasis at the host vibrio interface: lessons from intracellular vibrio transcriptomics. Environ 785 Microbiol 18: 875-888.

788 Vezzulli, L., Pezzati, E., Stauder, M., Stagnaro, L., Venier, P., and Pruzzo, C. (2015) Aquatic ecology 789 of the oyster pathogens Vibrio splendidus and Vibrio aestuarianus. Environ Microbiol 17: 1065-1080. 


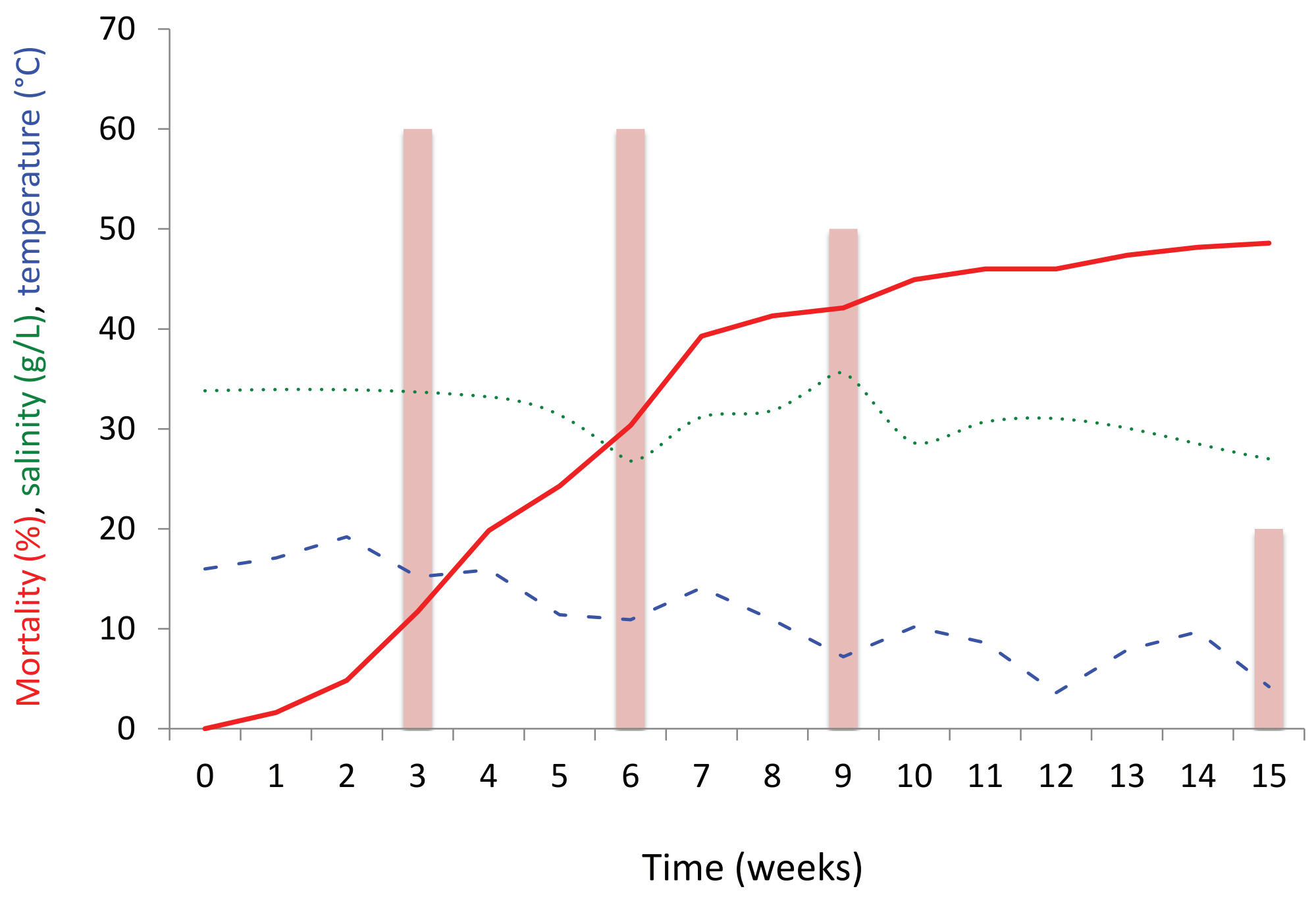


Total vibrio

V. aestuarianus

Total vibrio

V. aestuarianus

Total vibrio

V. aestuarianus

Total vibrio

V. aestuarianus

Total vibrio

V. aestuarianus

Total vibrio

V. aestuarianus
Sediment

Zooplancton

$>60 \mu \mathrm{m}$

Large phytoplancton and organic particles 60-5 $\mu \mathrm{m}$

Smaller organic particles 5-1 $\mu \mathrm{m}$

Free-living bacteria $<1 \mu \mathrm{m}$

Oyster hemolymph

0

3

6

9

15

Time (weeks) 


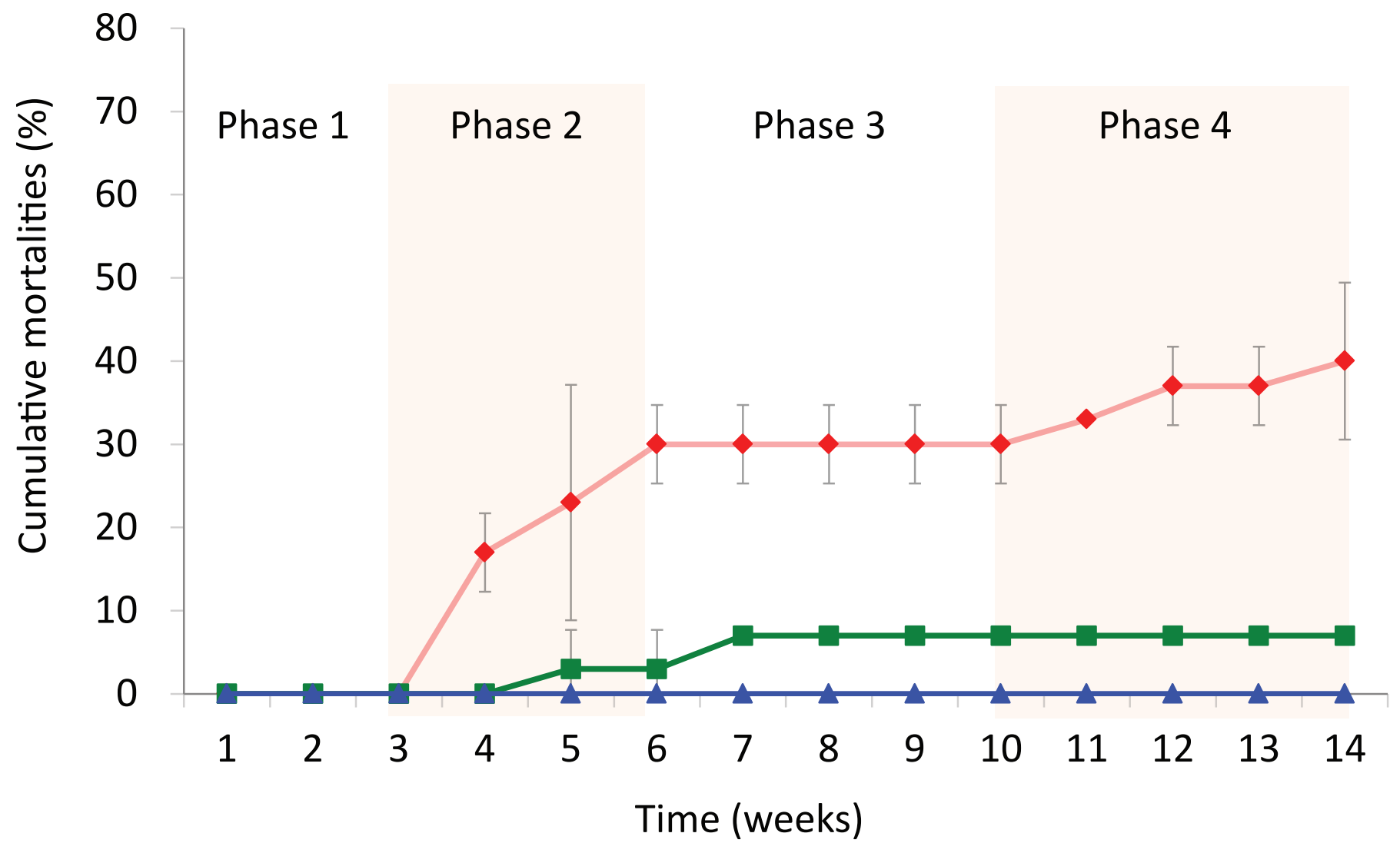



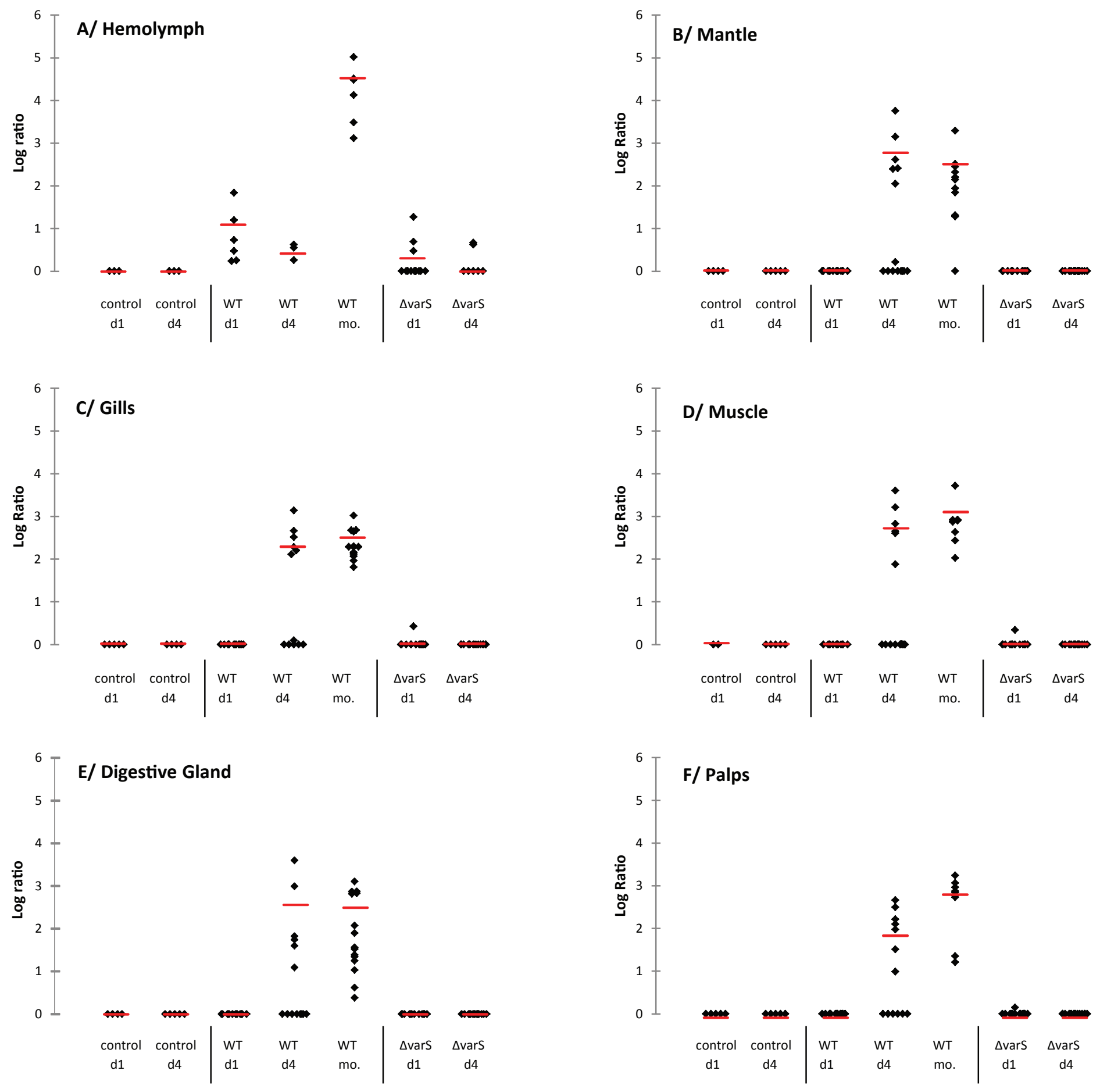


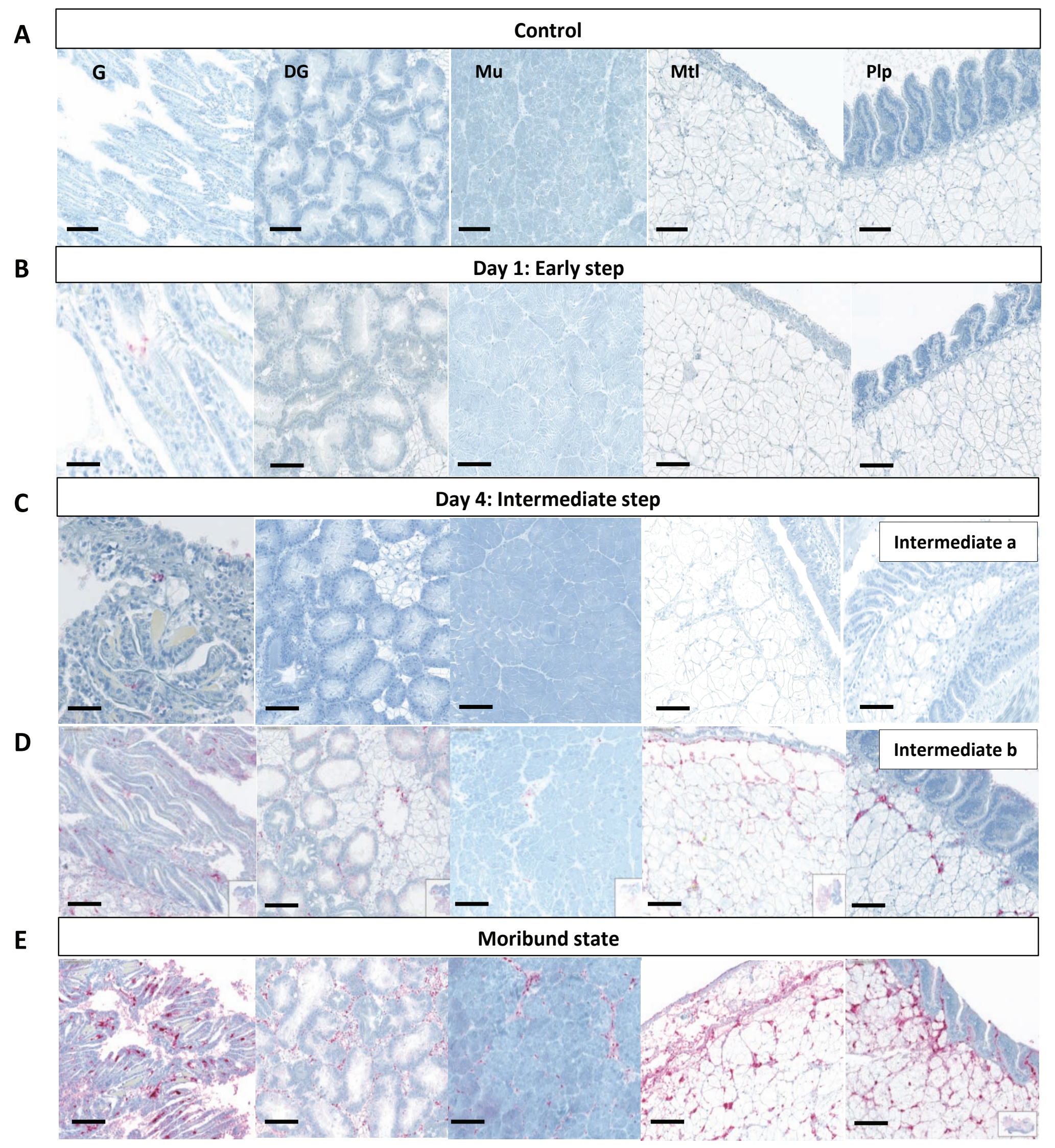



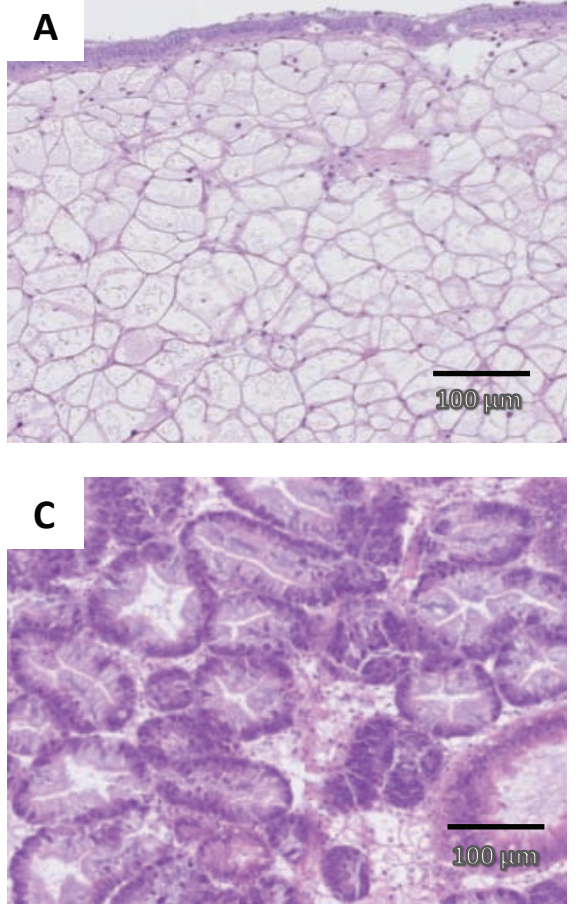

\section{E}

100рат

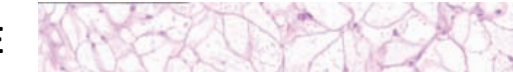

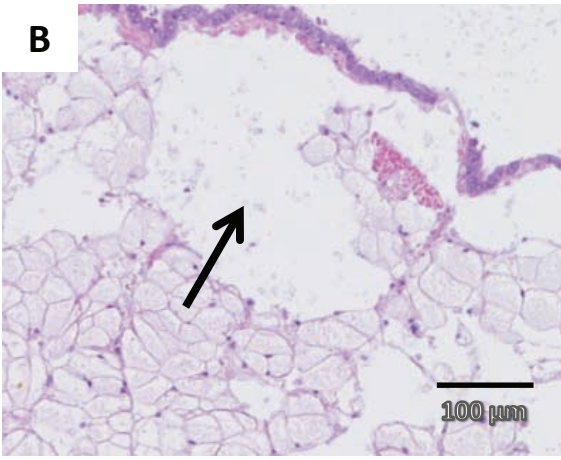

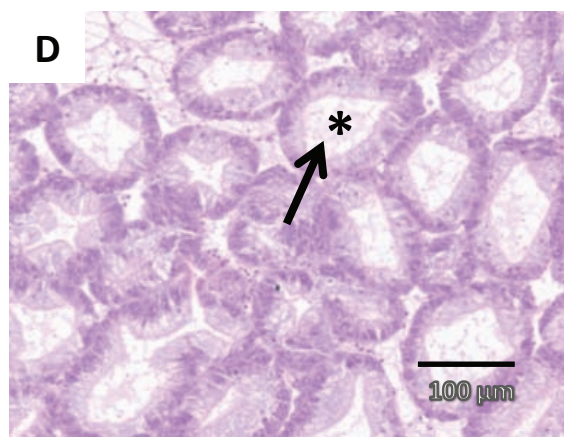

G

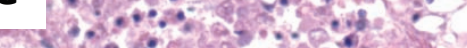

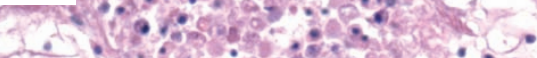

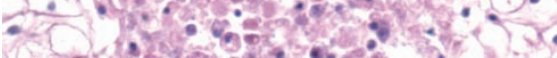

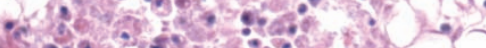

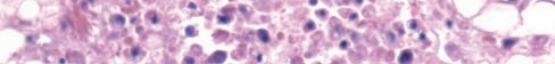

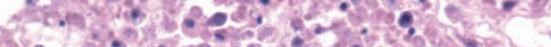

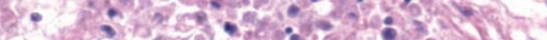

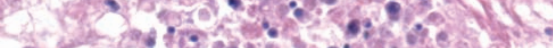
Auk.

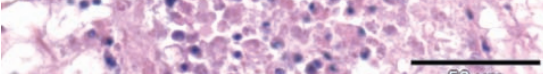

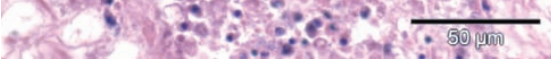
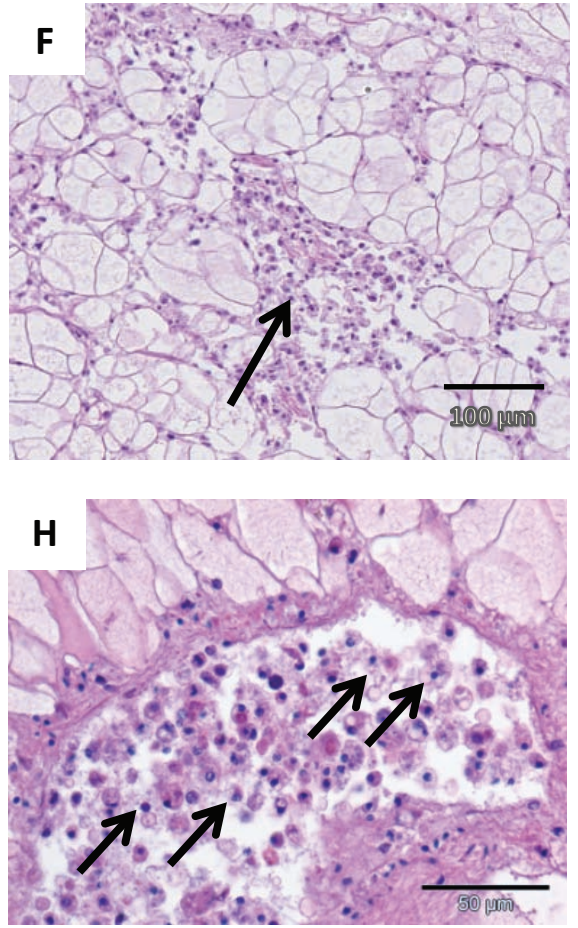

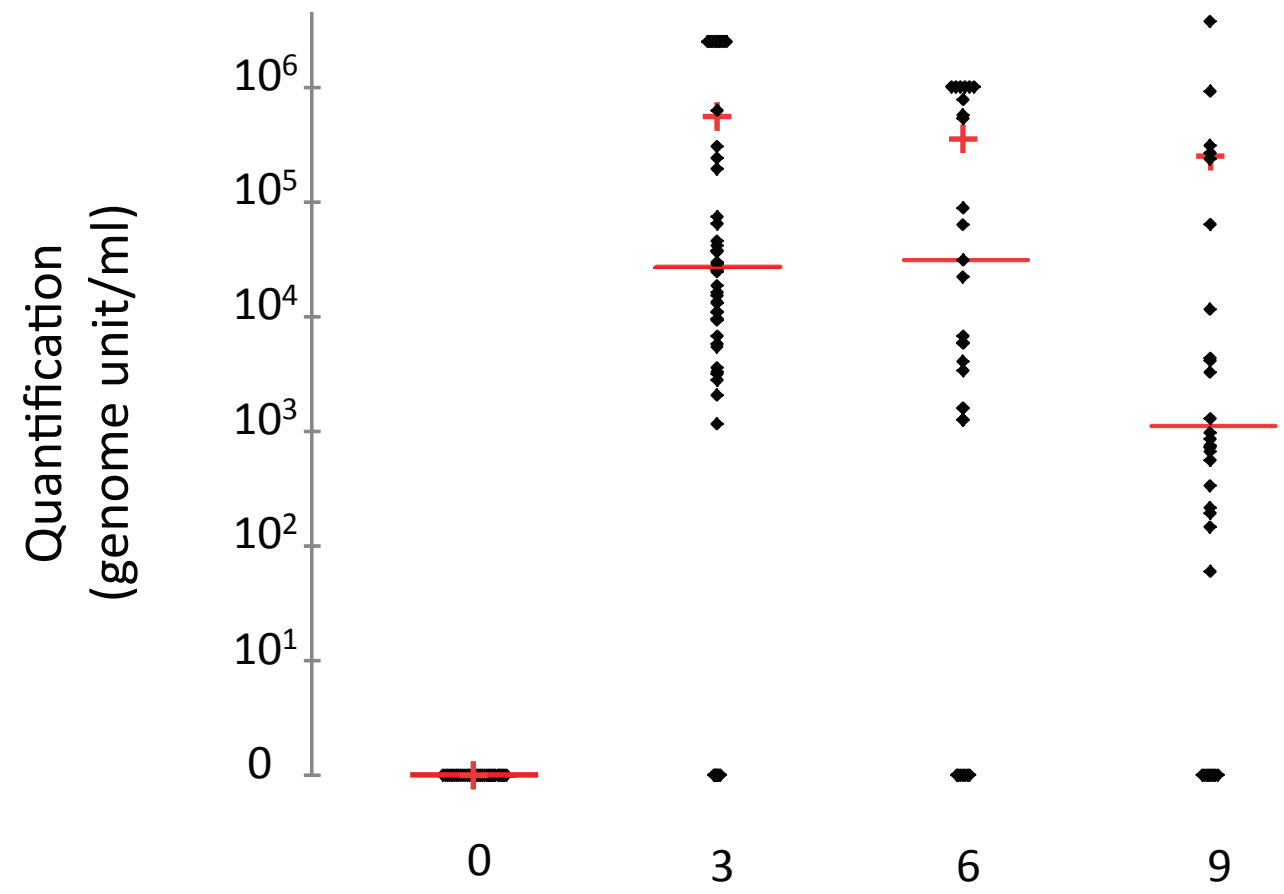

3

6

9

15

Time (weeks) 


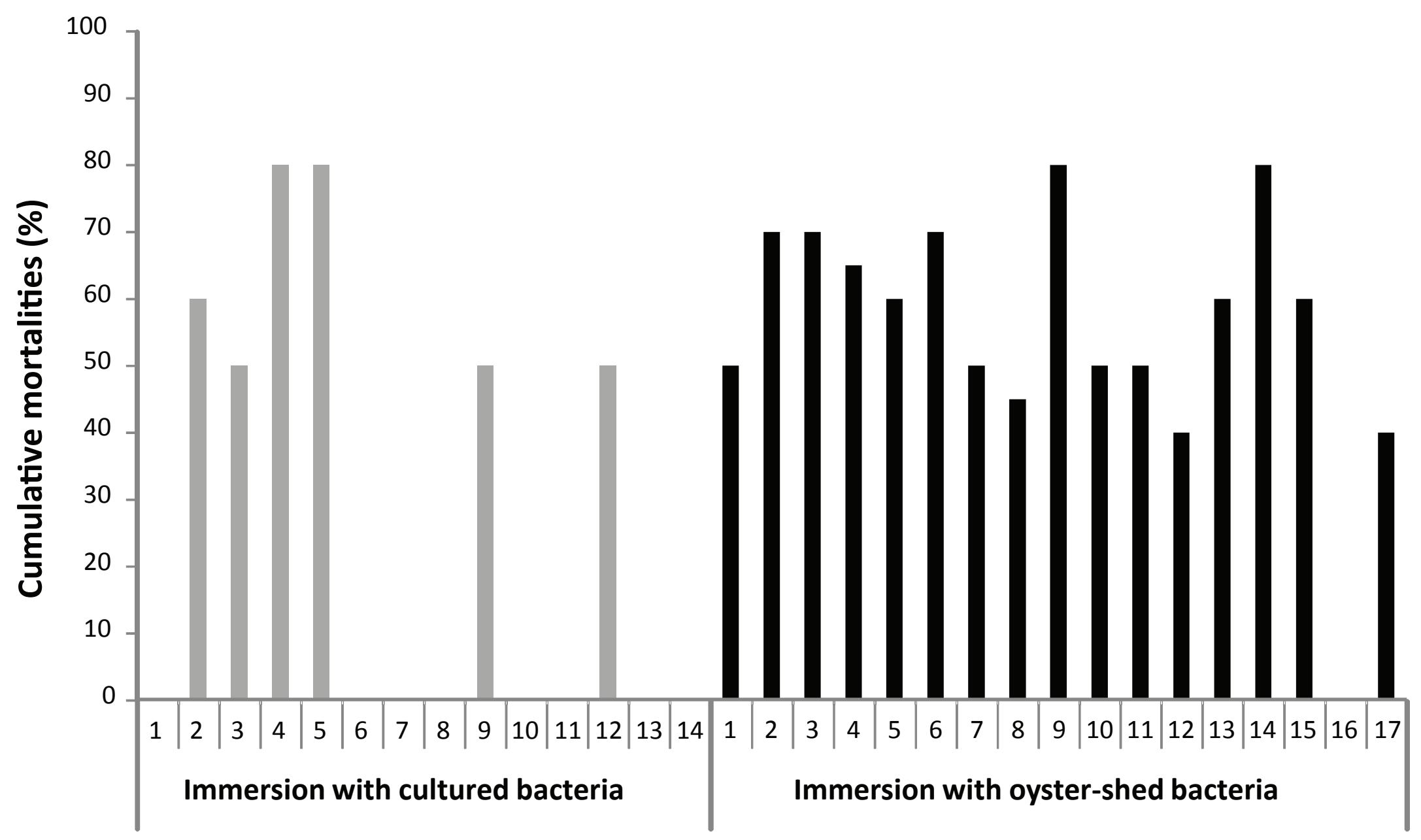

